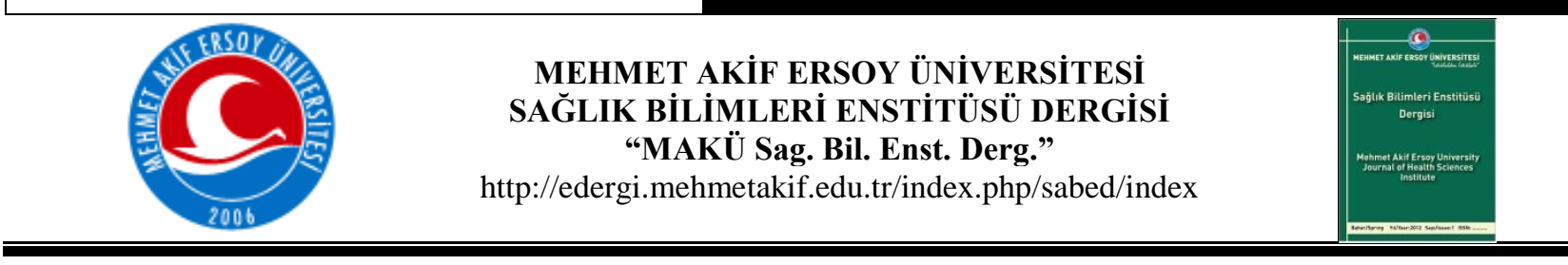

\title{
Yaşlı Bireylerin İlaç Kullanımına İlişkin Davranışlarının Sosyo-Demografik Değişkenler Açısından İncelenmesi
}

\author{
Investigation of Behaviors Related to Drug Use of the Elderly Individuals in \\ Terms of Socio-demographic Variables
}

\author{
Deniz Say Şahin ${ }^{1}$, Özlem Özer², Melek Zubaroğlu Yanardağ ${ }^{1}$ \\ ${ }^{1}$ Mehmet Akif Ersoy Üniversitesi, İktisadi ve İdari Bilimler Fakültesi, Sosyal Hizmet Bölmü, Burdur, \\ TÜRKIYE \\ ${ }^{2}$ Mehmet Akif Ersoy Üniversitesi, İktisadi ve İdari Bilimler Fakültesi, Sağlık Yönetimi Bölmü, Burdur, \\ TÜRKIYE
}

\begin{abstract}
The aim of this study is to examine the behavior of drug use in aged 65 and over and to determine whether their socio-demographic characteristics are effective on drug use behaviors. The universe of this study is composed of participants being 65 years old and over who live in Burdur province center $(\mathrm{N}=12.378)$. In the study, totally 479 questionnaires were implemented. The data were collected from questionnaires by the researchers between February 12-25, 2018. Descriptive statistics, independent sample $t$ test and one way analysis of variance (Anova) were used in the analysis of the data. According to the results obtained by the study, it was determined that participants' drug use behaviors were moderate. There was also a significant difference between drug use behaviors according to participants' incomes, it was determined that drug use behaviors of the participants whose income was 2000 TL or more were higher. İn order to develop appropriate drug use behaviours, it is important to conduct training an information studies from the moment the medicines are prescribed.
\end{abstract}

\section{Key words: Drug use behavior, drug, older, age 65 and over.}

İletișim Adresi: Dr. Öretim Üyesi Deniz Say Sahin, MAKÜ İktisadi ve İdari Bilimler Fakültesi, Sosyal Hizmet Bölmü, Burdur, Türkiye

E-posta: saysahind@mehmetakif.edu.tr

Tel: +90 5052362620

Kaynak göstermek için: Sahin DS, Özer Ö, Yanardağ MZ. 2018. Yaşlı Bireylerin İlaç Kullanımına İlişkin Davranışlarının SosyoDemografik Değişkenler Açısından İncelenmesi. MAKÜ Sag. Bil. Enst. Derg. 6(1): 15-25. doi: 10.24998/maeusabed.420301
Öz: $\mathrm{Bu}$ çalışmanın amacı, 65 yaş ve üstü bireylerin ilaç kullanımına ilişkin davranışlarını incelemek ve sosyodemografik özelliklerin ilaç kullanım davranışları üzerinde etkili olup olmadığını ortaya koymaktır. Araştırmanın evrenini Burdur il merkezinde yaşayan 65 yaş ve üzeri bireyler oluşturmaktadır ( $\mathrm{N}=12.378)$. Çalışmada toplam 479 kişiye anket uygulanmıştır. Veriler anket aracılığıyla araştırmacılar tarafından 12-25 Şubat 2018 tarihleri arasında toplanmıştır. Verilerin analizinde tanımlayıcı istatistikler, bağımsız örneklem $t$ testi ve tek yönlü varyans analizi (Anova) kullanılmıştır. Çalışmadan elde edilen sonuçlara göre, katılımcıların ilaç kullanım davranışlarının orta düzeyde olduğu belirlenmiştir. Katılımcıların gelirlerine göre ilaç kullanım davranışları arasında anlamlı fark bulunmuş, geliri 2000 TL ve üstü olan katılımcıların ilaç kullanım davranışlarının daha yüksek olduğu tespit edilmiştir. Uygun ilaç kullanım davranışlarının geliştirilmesi için ilaçların reçete edildiği andan itibaren eğitim ve bilgilendirme çalışmalarının yapılması önemlidir.

Anahtar sözcükler: İlaç kullanım davranışı, ilaç, yaşılı, 65 yaş ve üstü

Geliş tarihi: 02.05.2018 Kabul tarihi: 26.06.2018 


\section{Giriş}

Çocukluk ve gençlik gibi yaşl1lık da, doğal yaşam döngüsünün bir dönemine işaret etmektedir. Yaşl1lık süreci, bireylerde pek çok açıdan hassas bir yaşam dönemi olarak ortaya çıkmaktadır. Dünya Sağlık Örgütü yaşlılığı; "çevresel faktörlere uyum sağlayabilme yeteneğinin azalması" olarak tanımlamaktadır (Aydoğdu Kocadağ, 2016). Arpac1 ve diğerlerine (2008) göre yaşlılık; başlangıcı 60-65 yaş olarak kabul edilen, biyolojik, fizyolojik, duygusal ve fonksiyonel değişikliklerin meydana geldiği bir dönemdir. Yaşlanma ise canlı organizmaların, türe özel bir zaman süresinde, iç ve dış çevredeki değişikliklere uyum yeteneğinin azalması sonucu homeostazisi sürdüremedikleri yaşam dönemi olarak tanımlanmaktadır (Akan vd., 1999).

Gerek tıp alanındaki gerekse teknoloji alanındaki pek çok ilerleme; sağlık alanında koruyucu-önleyici hizmetlerin, erken teşhis ve tedavi hizmetlerinin, yeni ve alternatif tıp uygulamalarının gelişimi gibi pozitif sonuçları beraberinde getirmiştir. Bu sonuçlar dünya genelinde, bireylerin yaşam sürelerinin uzamasına ve nüfus piramidinin bu yönde şekillenmesine yol açmıştır. Dünyaya paralel bir şekilde Türkiye'de 65 yaş ve üstü yaşlı nüfus yüzdesi artış göstermiştir (TÜİK, 2014). TÜİK'in 2017 y1lı verilerine göre Türkiye'de toplam yaşlı nüfus, 6 milyon 895 bin 385 kişidir. 2017 y1lında dünya nüfusunun \%8,9'unu yaşlı nüfusun oluşturduğu bilinmektedir (TÜIKK, 2018a). TÜİK (2018b)'in 2018-2080 yıllarını kapsayan nüfus projeksiyonuna göre ise Türkiye'de 65 yaş ve üzerindeki nüfus yüzdesinin 2018 yılında \%8,7 olacağı, 2023 yılında \%10,2'ye yükseleceği, 2080 yılına gelindiğinde ise \%25,6'ya yükseleceği tahmin edilmektedir.

Yaşlı nüfusun artışıyla doğru orantılı olarak yaşlılar arasında süreğen hastalık sayısında belirgin bir artış görülmekte ve bu da yaşlı nüfusun çocuk ve yetişkinlere göre daha yüksek düzeyde ilaç kullanmasına neden olmaktadır (Kuvvetlioğlu, 2011). Dolayısıyla yaşın ilerlemesiyle birlikte oluşan bazı fiziksel değişimler ve hastalıklar, yaşlı bireylerde aynı zamanda birden fazla miktarda (çoklu) ilaç kullanımını yaygınlaştırmaktadır (Akan vd., 1999). Farklı hastalıklar için farklı doktorlara gidilmesi, semptomları gidermeye yönelik ilaç kullanımı, akran ve yakınların tavsiyeleri, reçetesiz ilaç temin edilebilmesi polifarmasiye (çoklu ilaç kullanımı) zemin hazırlamaktadır (Bozkurt Bulakçı, 2013). Çoklu veya rastgele ilaç kullanımı yaşlı sağlığı açısından büyük bir tehdit oluşturmaktadır. Rastgele ilaç 
Yaşlı Bireylerin İlaç Kullanımına İlişkin Davranışlarının Sosyo-demografik Değişkenler Açısından İncelenmesi

Investigation of Behaviors Related to Drug Use of the Elderly Individuals in Terms of Socio-demographic Variables

kullanımının yaygın olması, ilerleyen yaşa bağlı olarak duyusal işlevlerde azalma, kullanılan ilaçların hatırlanamaması, ilaç tedavisinin önemini algılayamama veya bunun önemini kavrayamama, bulantı, kusma gibi yan etkilerin görülmesi vb. gibi nedenlerle yaşlılar, uygun olmayan zamanlarda veya uygun olmayan dozlarda ilaç kullanabilmektedir (Akgün, 2016). Gökçe Kutsal (2006)'a göre çoklu ilaç kullanımına zemin hazırlayan bazı faktörler; birden fazla doktordan hizmet alınması ve bu nedenle birden fazla sayıda reçeteye sahip olunması, reçetelerde sayıca çok ilaca yer verilmesi, hekimlerin çok sayıda ilaç reçete etmeye meyilli olmaları, birçok hastanın fazla sayıda ilaç reçete edilmesi ile ilgili beklenti içinde olmaları, tanıya yönelik ilaç yazılması yerine şikayet ve hastalık belirtileri doğrultusunda ilaç tüketilmesi, önceki ilacı bırakıp farklı bir ilaca yönelme, hastanın kullandığı ilacın talep üzerine yeniden yazılması, reçete olmaksızın ilaç satışı ve aile üyelerinden veya diğer yakınlardan ilaç temin edilmesidir.

Gökçe Kutsal (2006) yaşı bireylerde ilaç kullanımına yönelik bir takım öneriler sunmuştur. Bu öneriler;

- İlaç tedavisinin gerekliliğinin değerlendirilmesi,

- Hâlihazırda kullanılan ilaç, sigara ve alkol gibi maddelerin bilinmesi,

- Reçetey edilenlerin farmakolojik özelliklerinin bilinmesi,

- Yaşlı grupta tedavi sürecine düşük dozlarla başlanılması,

- Dozaj, ilaç kombinasyonları ve tedaviye son verme seçeneklerinin dikkatlice belirlenmesi,

- Yaşıının tedaviye uyum sağlaması için tedavinin olabildiğince basitleştirilmesi,

- Tedavinin sık sık gözden geçirilmesi,

- Hastanın ihtiyaç duymadığı ilaçlarının tedavi protokolünden çıkarılması şeklindedir.

Yaşlı grupta çoklu ilaç kullanımının neden olduğu riskleri azaltmak için Dünya Sağlık Örgütü tarafından, "kişilerin klinik bulgularına ve bireysel özelliklerine göre uygun ilacı, uygun süre ve dozda, en düşük fiyatta ve kolayca sağlayabilmeleri olarak tanımlanan "akılcı ilaç kullanımı" yaklaşımı uygulanmaktadır (Kuvvetlioğlu, 2011; WHO, 1985). Akılcı ilaç kullanımı, hastaya doğru tanının konmasından başlayıp, hastanın özelliklerine göre en etkin tedavinin seçilmesi, tedaviye başlanması, sonuçların izlenmesi ve değerlendirmesini içeren sistematik bir yaklaşımdır (Ekenler ve Koçoğlu, 2016). Bir sağlık hizmeti uygulaması olarak akılcı ilaç kullanımından başlıca beklentiler ise; doğru, etkin ve hızlı ilaç tedavisi ile tedavi 
Yaşlı Bireylerin İlaç Kullanımına İlişkin Davranışlarının Sosyo-demografik Değişkenler Açısından İncelenmesi

Investigation of Behaviors Related to Drug Use of the Elderly Individuals in Terms of Socio-demographic Variables

hizmetlerinde etkinlik ve güvenliğin artması ve genel sağlık harcamalarında azalma ve tasarruf sağlanmasıdır (Abacıoğlu, 2005). Böylece akılcı ilaç kullanımı, gereksiz ilaç kullanımının önüne geçen, profesyonel sağlık hizmeti düzlemini koruyan ve sağlığın geliştirilmesini destekleyen bir yaklaşımdır. Akılcı ilaç kullanımı bu bağlamıyla olumlu ilaç kullanımı davranışlarını da içinde almaktadır. $\mathrm{Bu}$ araştırmanın konusu yaşlılarda ilaç kullanımına ilişkin davranışların incelenmesidir. Bu konunun seçilmesinin nedeni, olumlu ilaç kullanımı davranışlarının yaşlı sağlığı açısından oldukça kritik bir öneme sahip olması ve Burdur ilinde yüksek düzeyde (\%14) yaşlı popülasyonun yaşıyor olmasıdır.

\section{Materyal ve Metod}

\section{Çalışmanın Amacı}

Bu çalışmanın amacı, 65 yaş ve üstü bireylerin ilaç kullanımına ilişkin davranışlarını incelemek ve sosyo-demografik özelliklerin ilaç kullanım davranışları üzerinde etkili olup olmadığını ortaya koymaktır.

\section{Çalıșmanın Yöntemi}

Çalışma epidemiyolojik tipte tanımlayııı bir araştırmadır.

\section{Evren ve Örneklem}

Araştırmanın evrenini Burdur il merkezinde yaşayan 65 yaş ve üstü bireyler oluşturmaktadır. 2017 Adrese Dayalı Nüfus Kayıt Sistemi'ne göre Burdur il merkezinin 65 yaş ve üstü nüfusu $12.378^{\prime}$ dir. Bu çalışmada örneklem büyüklüğü, ana kitle oranlarına dayalı kümelendirilmemiş tek aşamalı tesadüfî olasılık örnekleme yöntemi ile belirlenmiştir (Collins, 1986). Çalışmada örneklem büyüklüğ̈̈ $\% 5$ kabul edilebilir hata seviyesinde, $\% 95$ güven aralığında ve olayın ana kitle içinde gerçekleşme olasılığ $\% 50$ alınarak 378 kişi olarak hesaplanmıştır. Ancak çalışmada toplam 478 anket yapılmıştır. Anketler, 12-25 Şubat 2018 tarihleri arasında toplanmıştır.

\section{Veri Toplama Aracı}

Araştırmada yaşlıların sosyo-demografik özelliklerini ölçmek için cinsiyet, yaş, medeni durum, eğitim durumu, meslek, gelir durumu, kronik hastalık durumu, devamlı ilaç kullanma durumu ve sağlık kurumuna gitme sıklığı gibi 9 sorudan oluşan kişisel bilgi formu kullanılmıştır. Yaşlıların ilaç kullanım davranışlarını ölçmek için ise Arpacı ve diğerlerinin 
Yaşlı Bireylerin İlaç Kullanımına İlişkin Davranışlarının Sosyo-demografik Değişkenler Açısından İncelenmesi

Investigation of Behaviors Related to Drug Use of the Elderly Individuals in Terms of Socio-demographic Variables

(2008) geliştirdiği “Yaşlının İlaç Kullanım Davranışları” ölçeği kullanılmıştır. Ölçek 17 maddeden oluşmakta ve ölçekte 8 olumlu $(1,3,4,5,6,13,16,17)$ ve 9 olumsuz $(2,7,8,9$, $10,11,12,14,15)$ ifade yer almaktadır. Ölçekte maddelere ilişkin katılım düzeyleri "Her zaman=5", ve "Hiçbir zaman=1" şeklinde puanlandırılmaktadır. Ölçekten maksimum 85 ve minimum 17 puan alınabilmektedir.

\section{Veri Toplama Aracinın Uygulanması}

Veriler araştırmacılar tarafindan bir devlet hastanesine muayene için başvurdukları sırada araştırmaya katılmayı kabul eden yaşlılardan yüzyüze görüşme yöntemi ile anket formu ile toplanmıştır. Anketler, yaşlıların verdikleri cevaplara göre araştırmacılar tarafından doldurulmuştur. Anketlerin uygulanması ise yaklaşık olarak 10-15 dakika sürmüştür.

\section{Etik İzin}

Çalışmanın gerçekleştirilebilmesi için Mehmet Akif Ersoy Üniversitesi Girişimsel Olmayan Klinik Araştırmalar Etik Kurulu'ndan (Karar No:GO2017/19) gerekli izinler alınmıştır. Katılımcılara çalışmaya katılımın gönüllü olduğu ve toplanan verilerin sadece bilimsel amaçla kullanılacağı belirtilmiştir.

\section{Verilerin Analizi}

$\mathrm{Bu}$ çalışmadaki istatistiksel analizler SPSS 20.0 programı kullanılarak gerçekleştirilmiştir. Verilerin analizinde yüzdelik, ortalama \pm standart sapma, bağımsız örneklem $\mathrm{t}$ testi ve tek yönlü varyans analizi kullanılmıştır. Çalışmada yaş, cinsiyet, medeni durum ve kronik hastalığa sahip olma durumu arasında fark olup olmadığını test etmek için bağımsız örneklem t testi kullanılırken; eğitim durumu, meslek, gelir durumu ve sağlık kurumuna gitme sıklığı arasındaki farklılığı test etmek için tek yönlü varyans analizi kullanılmıştır. Varyans analizinde farklılı̆̆ın hangi grup ya da gruplardan kaynaklandığının belirlenmesi için ise Tukey testinden yararlanılmıştır.

\section{Bulgular}

Araştırmaya katılan yaşlıların sosyo-demografik özellikleri incelendiğinde katılımcıların \%51.1'inin erkek; \%68.9'unun 65-69 yaş aralığında; \%85.4'ünün evli; \%68.5'inin ilkokul düzeyinde bir eğitim düzeyine sahip olduğu belirlenmiştir. Katılımcıların \%40.9'unun ev hanımlarından oluştuğu ve \%44.5'inin de 1600-1999 TL gelir düzeyine sahip 
Yaşlı Bireylerin İlaç Kullanımına İlişkin Davranışlarının Sosyo-demografik Değişkenler Açısından İncelenmesi

Investigation of Behaviors Related to Drug Use of the Elderly Individuals in Terms of Socio-demographic Variables

olduğu saptanmıştır. Katılımcıların \%52.0’si herhangi bir kronik rahatsızlığa sahip olduğunu ve \%68.7'si de devamlı olarak bir ilaç kullandığını belirtmiştir. Katılımcıların \%34.9’u yılda 3-5 kez bir sağlık kurumuna gittiğini, \%16.5'i ise $11 \mathrm{kez}$ ve daha fazla sağlık kurumuna başvurduğunu ifade etmiştir (Tablo 1).

Tablo 1. Araştırmaya Katılan Yaşlıların Sosyodemografik Özelliklerinin Dağılımı

\begin{tabular}{|c|c|c|c|}
\hline Değişkenler & & Sayı & $\%$ \\
\hline \multirow[t]{2}{*}{ Cinsiyet } & Kadın & 234 & 48.9 \\
\hline & Erkek & 245 & 51.1 \\
\hline \multirow[t]{2}{*}{ Yaş } & $65-69$ & 330 & 68.9 \\
\hline & $\geq 70$ & 149 & 31.1 \\
\hline \multirow[t]{2}{*}{ Medeni Durum } & Evli & 409 & 85.4 \\
\hline & Bekâr & 70 & 14.6 \\
\hline \multirow[t]{4}{*}{ Eğitim Durumu } & İlkokul & 328 & 68.5 \\
\hline & Ortaokul & 64 & 13.4 \\
\hline & Lise & 60 & 12.5 \\
\hline & Önlisans/Lisans & 27 & 5.6 \\
\hline \multirow[t]{5}{*}{ Mesleğiniz } & Ev Hanımı & 196 & 40.9 \\
\hline & Çiftçi & 48 & 10.0 \\
\hline & İşçi & 48 & 10.0 \\
\hline & Emekli & 138 & 28.8 \\
\hline & Diğer & 49 & 10.2 \\
\hline \multirow[t]{3}{*}{ Gelir Durumu } & $\leq 1599$ & 131 & 27.3 \\
\hline & 1600-1999 & 213 & 44.5 \\
\hline & $\geq 2000$ & 135 & 28.2 \\
\hline Kronik Hastalık Sahibi Olma & Evet & 249 & 52.0 \\
\hline Durumu & Hayır & 230 & 48.0 \\
\hline \multirow[t]{2}{*}{ Devamlı İlaç Kullanma Durumu } & Evet & 329 & 68.7 \\
\hline & Hayır & 150 & 31.3 \\
\hline Sağlık Kurumuna Gitme Sıklığı & Hiç Gitmiyorum & 31 & 6.5 \\
\hline \multirow[t]{4}{*}{ (Y1llik) } & $1-2$ & 113 & 23.6 \\
\hline & $3-5$ & 167 & 34.9 \\
\hline & $6-10$ & 89 & 18.6 \\
\hline & 11 ve üstü & 79 & 16.5 \\
\hline Toplam & & 479 & 100 \\
\hline
\end{tabular}

Araştırmaya katılanların İlaç Kullanım Davranışı Ölçeği ortalaması 3.18 olarak belirlenmiştir. Araştırmaya katılan yaşlıların ilaç kullanım davranışları orta seviyededir (Tablo 2).

Tablo 2. Katılımcıların İlaç Kullanım Davranışı Ölçeği Ortalama ve Standart Sapma Değerleri

\begin{tabular}{lccccc}
\hline Değişken & Ortalama & $\begin{array}{c}\text { Standart } \\
\text { Sapma }\end{array}$ & Min & Max & $\begin{array}{c}\text { Cronbach } \\
\text { Alpha }\end{array}$ \\
\hline İlaç Kullanım Davranışı & 3.18 & 0.49 & 1.41 & 4.35 & 0.586 \\
\hline
\end{tabular}


Yaşlı Bireylerin İlaç Kullanımına İlişkin Davranışlarının Sosyo-demografik Değişkenler Açısından İncelenmesi

Investigation of Behaviors Related to Drug Use of the Elderly Individuals in Terms of Socio-demographic Variables

Katılımcıların yaşlarına ve cinsiyetlerine göre ilaç kullanım davranışları arasında anlamlı fark bulunamamıştır ( $>0.05$ ) (Tablo 3). Anlamlı fark bulunamamakla beraber 65-69 yaş aralığında olan, kadın katılımcıların, ilaç kullanım davranışlarının daha yüksek olduğu tespit edilmiştir.

Tablo 3. Araştırmaya Katılanların Yaşlarına ve Cinsiyetlerine Göre İlaç Kullanım Davranışları

\begin{tabular}{|c|c|c|c|c|c|c|c|c|}
\hline & \multicolumn{4}{|c|}{ Yaş } & \multicolumn{4}{|c|}{ Cinsiyet } \\
\hline & \multicolumn{2}{|c|}{$65-69$} & \multicolumn{2}{|c|}{70 ve üstü } & \multicolumn{2}{|c|}{ Kadın } & \multicolumn{2}{|c|}{ Erkek } \\
\hline & $\overline{\mathbf{X}}^{*}$ & SS** & $\overline{\mathbf{X}}$ & SS & $\overline{\mathbf{X}}$ & SS & $\overline{\mathbf{X}}$ & SS \\
\hline \multirow[t]{2}{*}{ İlaç Kullanım Davranışı } & 3.19 & 0.50 & 3.16 & 0.47 & 3.20 & 0.50 & 3.16 & 0.48 \\
\hline & \multicolumn{4}{|c|}{$\mathrm{t}=0.688 ; \mathrm{p}^{* * *}=0.492$} & \multicolumn{4}{|c|}{$\mathrm{t}=0.864 ; \mathrm{p}^{* * *}=0.388$} \\
\hline
\end{tabular}

* Ortalama, ** Standart Sapma , *** Bağımsız örneklem t testi

Katılımcıların eğitim durumuna göre ilaç kullanım davranışları arasında anlamlı fark bulunmuştur $(\mathrm{p}<0.05)$ (Tablo 4). Araştırmada önlisans/lisans eğitim düzeyine sahip katılımcıların ilaç kullanım davranışlarının daha yüksek olduğu tespit edilmiştir.

Tablo 4. Araştırmaya Katılanların Eğitim Durumuna Göre İlaç Kullanım Davranışları

\begin{tabular}{|c|c|c|c|c|c|c|c|c|}
\hline & \multicolumn{8}{|c|}{ Eğitim Durumu } \\
\hline & \multicolumn{2}{|c|}{ İlkokul } & \multicolumn{2}{|c|}{ Ortaokul } & \multicolumn{2}{|c|}{ Lise } & \multicolumn{2}{|c|}{ Önlisans/Lisans } \\
\hline & $\overline{\mathbf{X}} *$ & $\mathbf{S S} * *$ & $\overline{\mathbf{X}}$ & SS & $\overline{\mathbf{x}}$ & SS & $\overline{\mathbf{X}}$ & SS \\
\hline \multirow[t]{2}{*}{ İlaç Kullanım Davranışı } & 3.17 & 0.47 & 3.09 & 0.52 & 3.28 & 0.49 & 3.33 & 0.55 \\
\hline & \multicolumn{8}{|c|}{$\mathrm{F}=2.536 ; \mathbf{p}^{* * *}=\mathbf{0 . 0 4 6}$} \\
\hline
\end{tabular}

* Ortalama, ** Standart Sapma , *** Tek yönlü varyans analizi

Tablo 5'de katılımcıların gelirlerine göre ilaç kullanım davranışları arasında anlamlı fark bulunmuştur $(\mathrm{F}=3.332 ; \mathrm{p}<0.05)$. Geliri $2000 \mathrm{TL}$ ve üstü olan katılımcıların ilaç kullanım davranışları daha yüksektir.

Tablo 5. Araştırmaya Katılanların Gelirlerine Göre İlaç Kullanım Davranışları

\begin{tabular}{|c|c|c|c|c|c|c|}
\hline & \multicolumn{6}{|c|}{ Gelir } \\
\hline & \multicolumn{2}{|c|}{1599 ve daha az ${ }^{(1)}$} & \multicolumn{2}{|c|}{$1600-1999^{(2)}$} & \multicolumn{2}{|c|}{2000 ve üstü ${ }^{(3)}$} \\
\hline & $\overline{\mathrm{X}} *$ & $\mathbf{S S}^{* *}$ & $\overline{\mathbf{x}}$ & SS & $\overline{\mathbf{X}}$ & SS \\
\hline \multirow{2}{*}{ İlaç Kullanım Davranış1 } & 3.11 & 0.46 & 3.17 & 0.49 & 3.26 & 0.50 \\
\hline & \multicolumn{6}{|c|}{$\begin{array}{c}\mathrm{F}=3.332 ; \mathbf{p}^{* * *}=\mathbf{0 . 0 3 7} \\
1-3 ; \mathrm{p}=0.030\end{array}$} \\
\hline
\end{tabular}

* Ortalama, ** Standart Sapma, ***Tek yönlü varyans analizi 
Yaşlı Bireylerin İlaç Kullanımına İlişkin Davranışlarının Sosyo-demografik Değişkenler Açısından İncelenmesi

Investigation of Behaviors Related to Drug Use of the Elderly Individuals in Terms of Socio-demographic Variables

Katılımcıların medeni durumlarına ve kronik hastalık durumlarına göre ilaç kullanım davranışları arasında anlamlı fark bulunamamıştır ( $p>0.05)$ (Tablo 6). Anlamlı fark bulunamamakla beraber bekarların ve herhangi bir kronik hastalığa sahip olanların ilaç kullanım davranışlarının daha yüksek olduğu tespit edilmiştir.

Tablo 6. Araştırmaya Katılanların Medeni Durumlarına ve Kronik Hastalık Durumlarına Göre İlaç Kullanım Davranışları

\begin{tabular}{cccccccccc}
\hline & \multicolumn{4}{c}{ Medeni Durum } & \multicolumn{3}{c}{ Kronik Hastalık Durumu } \\
\cline { 2 - 9 } & \multicolumn{3}{c}{ Bekar } & \multicolumn{2}{c}{ Evli } & \multicolumn{2}{c}{ Evet } & \multicolumn{2}{c}{ Hayır } \\
\cline { 2 - 9 } & $\overline{\mathbf{X}} *$ & SS** & $\overline{\mathbf{X}}$ & SS & $\overline{\mathbf{X}}$ & SS & $\overline{\mathbf{X}}$ & SS \\
\hline İlaç Kullanım Davranış1 & 3.19 & 0.47 & 3.18 & 0.49 & 3.22 & 0.51 & 3.14 & 0.46 \\
& & & $\mathrm{t}=0.109 ; \mathrm{p}^{* * *}=0.913$ & & & $\mathrm{t}=1.833 ; \mathrm{p}^{* * *}=0.067$ & \\
\hline
\end{tabular}

* Ortalama, ** Standart Sapma, ***Bağımsız örneklem t testi

Katılımcıların sağlık kurumuna gitme sıklıklarına göre ilaç kullanım davranışları arasında anlamlı fark bulunamamıştır ( $\mathrm{p}>0.05)$ (Tablo 7). Anlamlı fark bulunamamakla beraber sağlık kurumuna hiç gitmeyenlerin ilaç kullanım davranışlarının daha yüksek olduğu tespit edilmiştir.

Tablo 7. Araştırmaya Katılanların Sağlık Kurumuna Gitme Sıklıklarına Göre İlaç Kullanım Davranışları

\begin{tabular}{|c|c|c|c|c|c|c|c|c|c|c|}
\hline & \multicolumn{10}{|c|}{ Sağlık Kurumuna Gitme Sıklığı } \\
\hline & \multicolumn{2}{|c|}{ Hiç Gitmiyorum } & \multicolumn{2}{|c|}{$1-2$} & \multicolumn{2}{|c|}{$3-5$} & \multicolumn{2}{|c|}{$6-10$} & \multicolumn{2}{|c|}{11 ve üstü } \\
\hline & $\overline{\mathbf{X}} *$ & $\mathbf{S S}^{* *}$ & $\overline{\mathbf{X}}$ & SS & $\overline{\mathbf{X}}$ & SS & $\overline{\mathbf{X}}$ & SS & $\overline{\mathbf{X}}$ & SS \\
\hline İlaç Kullanım & 3.29 & 0.46 & 3.12 & 0.48 & 3.19 & 0.45 & 3.22 & 0.53 & 3.16 & 0.54 \\
\hline Davranışı & \multicolumn{10}{|c|}{$\mathrm{F}=0.977 ; \mathrm{p}^{* * *}=0.420$} \\
\hline
\end{tabular}

* Ortalama, **Standart Sapma *** Tek yönlü varyans analizi

Araştırmaya katılanların mesleki durumlarına göre ilaç kullanım davranışları arasında anlamlı fark bulunamamıştır ( $>0.05$ ) (Tablo 8). Anlamlı fark bulunamamakla beraber işçilerin ilaç kullanım davranışlarının daha düşük düzeyde olduğu tespit edilmiştir.

Tablo 8. Araştırmaya Katılanların Mesleki Durumlarına Göre İlaç Kullanım Davranışları

\begin{tabular}{|c|c|c|c|c|c|c|c|c|c|c|}
\hline & \multicolumn{10}{|c|}{ Meslek } \\
\hline & \multicolumn{2}{|c|}{ Ev Hanımı } & \multicolumn{2}{|c|}{ Çiftçi } & \multicolumn{2}{|c|}{ Emekli } & \multicolumn{2}{|c|}{ İşçi } & \multicolumn{2}{|c|}{ Diğer**** } \\
\hline & $\overline{\mathbf{X}^{*}}$ & $\mathbf{S S}^{* *}$ & $\overline{\mathbf{x}}$ & SS & $\overline{\mathbf{x}}$ & SS & $\overline{\mathbf{x}}$ & SS & $\overline{\mathbf{X}}$ & SS \\
\hline İlaç Kullanım & 3.17 & 0.51 & 3.17 & 0.44 & 3.21 & 0.48 & 3.12 & 0.44 & 3.24 & 0.54 \\
\hline Davranışı & \multicolumn{10}{|c|}{$\mathrm{F}=0.518 ; \mathrm{p}^{* * *}=0.723$} \\
\hline
\end{tabular}

* Ortalama, ** Standart Sapma, *** Tek yönlü varyans analizi, **** Esnaf, serbest meslek 
Yaşlı Bireylerin İlaç Kullanımına İlişkin Davranışlarının Sosyo-demografik Değişkenler Açısından İncelenmesi

Investigation of Behaviors Related to Drug Use of the Elderly Individuals in Terms of Socio-demographic Variables

\section{Tartışma}

Ülkelerdeki nüfus dinamiklerinin değişimi ile birlikte yaşlanan dünya kavramı daha s1k gündeme gelmektedir. Nufus içerisinde 65 yaş ve üzeri bireylerin artması, yaşlılık ve yaşlanma ile ilgili çalışmaların da ivme kazanmasına neden olmaktadır. Yaşlı populasyondaki sürekli ilaç kullanım oranlarının diğer yaş gruplarından fazla olması yaşlılardaki ilaç kullanımı araştırmalarına önem kazandırmaktadır.

Yaşlanmanın doğal sonuçlarından birisi olarak ortaya çıkan akut ve kronik hastalıklara bağlı olarak, yaşlıların ilaç kullanım yüzdeleri toplumun geneline göre artmaktadır (Gülhan, 2013). Bu çalışmanın amacı, yaşlı bireylerde ilaç kullanımına ilişkin davranışların bazı sosyodemografik değişkenler açısından incelenmesidir. Çalışmada yapılan analizler sonucunda yaşlıların ilaç kullanım davranışlarının orta seviyede olduğu belirlenmiştir.

Katılımcıların ilaç kullanım davranışına ilişkin puanları gelirlerine ve eğitim durumlarına göre istatistiksel olarak anlamlı farklılıklar göstermektedir Geliri ve eğitim seviyesi yüksek olan bireylerde ilaç kullanım davranışları daha yüksektir. Bu durum, geliri daha yüksek olan bireylerin ilaçlara erişim konusunda daha avantajlı olmasından kaynaklanabilir. Kuvvetlioğlu (2011)'un çalışmasında ise eğitim durumlarına göre yaşlıların ilaç kullanım ölçeği puan ortalamaları arasındaki farkın anlamlı olduğu bulunurken, ekonomik koşullara göre anlamlı düzeyde değişmediği bulunmuştur.

Çalışmada yaşlıların ilaç kullanım davranışlarına ilişkin puanlarının yaşlarına, cinsiyetlerine, medeni durumlarına, kronik hastalığa sahip olup olmamalarına, sağlık kurumuna gitme sıklıklarına ve mesleklerine göre istatistiksel olarak anlamlı bir fark oluşturmadığ 1 belirlenmiştir. İstatistiksel olarak anlamlı bir fark olmasa da kronik hastalığa sahip yaşlıların ilaç kullanım yüzdeleri daha yüksek bulunmuştur, bu durum yaşlıların hastalıkları nedeni ile düzenli ilaç kullanmaları gerektiği için olabilir. Ancak istatistiksel olarak anlamlı bir fark olmamasından da anlaşılacağı üzere kronik hastalığa sahip olmayan yaşlılar da kronik hastalığa sahip ve düzenli ilaç kullanan bireyler kadar ilaç kullanmaktadırlar. Yakınlarının tavsiyesiyle ilaç kullanımı yaşlılar arasında yaygın bir davranıştır. Özellikle yaşlı kadınlarda bu davranış, daha yüksek bir oranda sergilenebilmektedir (Arslan vd., 2000). Şahin ve Baydar (2006)'ın Ankara'da 65 yaş ve üzeri yaştaki yaşlılar üzerinde yaptıkları bir araştırmada, her iki yaşlıdan birinin sürekli olarak ilaç 
Yaşlı Bireylerin İlaç Kullanımına İlişkin Davranışlarının Sosyo-demografik Değişkenler Açısından İncelenmesi

Investigation of Behaviors Related to Drug Use of the Elderly Individuals in Terms of Socio-demographic Variables

kullandığı, kadınlarda çoklu ilaç kullanımının daha yaygın olduğu, kadınlar arasında doktor önerisi ve reçetesi doğrultusunda ilaç kullanımının daha yüksek olduğu tespit edilmiş̧ir.

Çalışmada, yaşlıların ilaç kullanım davranışlarının orta düzeyde olduğu saptanmıştır. Blanco-Reina ve diğerlerinin (2014) İspanya'da yaptıkları çalışmada toplumda yaşayan ve birinci basamak sağlık merkezlerine başvuran 407 yaşlı hastada uygunsuz ve çoklu ilaç kullanım yüzdesi \%44 olarak bulunmuştur. Jhaveri ve diğerlerinin (2014) Hindistan'da yapmış oldukları bir çalışmada sağlık merkezine başvuran ve yatı̧ı yapılan 676 yaşlıda (ortalama yaş: 72,7 ) uygunsuz ilaç kullanımı \%87,3 ile oldukça yüksek düzeyde saptanmıştır. Davidoff ve diğerlerinin (2015) ABD'de yaptıkları bir çalışmada uygunsuz ilaç kullanımı $\% 40,8$ olarak saptanmış ve en sık kullanılan uygunsuz ilaç ise Non Steroid Antienflamatuar ilaç olarak bildirilmiş̧tir. Esengen (2000) tarafından Türkiye'de 23 ilin huzurevlerinde yapılan bir araştırmada; huzurevi sakinleri tarafindan en sık kullanılan ilaçların kardiyovasküler sistem ilaçları ve analjezikler olduğu belirlenirken, çoklu ilaç kullanımı ile ilaç yan etkileri arasında da pozitif korelasyonlar saptanmıştır. Yine Gökçe Kutsal ve diğerlerinin (2009) ülkemizin 12 farklı şehrinde 65 yaş ve üzerindeki 1433 yaşlı ile görüşerek çoklu ilaç kullanımını araştırdığı çalışmada, araştırmaya katılan yaşlıların \%84,7'sinin sürekli kullandığı bir ilacı olduğu saptanmıştır. Bu araştırmada da sürekli ilaç kullanan yaşlıların düzeyi \%68.7 olarak bulunmuştur. Yaşlı popülasyondaki ilaç kullanım sıklığını belirlemeye yönelik çalışmalar göstermiştir ki ülkemizdeki ilaç kullanım istatistikleri yurtdı̧ında yapılan çalışmalar ile benzerlik göstermektedir ve yaşlılarda doğru ilaç kullanımı davranışlarının geliştirilmesi büyük önem taşımaktadır.

İlaç kullanımı anlaşılacağı üzere psikolojik ve sosyal faktörlerle de ilişkili bir bağlama sahiptir. Yaşlı bireyin psikolojik ve sosyal açıdan ihtiyaçlarının giderilmemesi onu sık sık sağlık kurumlarına başvurmaya ve reçete edilen ilaçlarla problemlerini çözme yoluna itebilmektedir. Gereksiz ilaç kullanımının yanı sıra reçete edilen gerekli ilaçların düzenli kullanımı için de yaşlıya sosyal destek verecek bir veya birden fazla aile bireyinin olması önemlidir. Yaşlının medeni durumu ve yanında kendisine bakım desteği sunabilecek birisinin (eşi gibi) bulunması da bu noktada katkı sağlayıcıdır. Bunun dışında eğitim durumu, meslek ve ekonomik gelir de düzenli ve doğru ilaç kullanımını büyük oranda etkileyen faktörlerdendir. Bahsedilen bu faktörler gerek sosyal ve psikolojik gerekse ekonomik desteğin yaşlı popülasyon için oldukça önemli olduğunu göstermektedir. Ülkemizde yaşl1lara yönelik 
Yaşlı Bireylerin İlaç Kullanımına İlişkin Davranışlarının Sosyo-demografik Değişkenler Açısından İncelenmesi

Investigation of Behaviors Related to Drug Use of the Elderly Individuals in Terms of Socio-demographic Variables

psikososyal destek hizmetlerinin geliştirilmesi aracilığıyla yaşlıların; bilgisel, duygusal ve elle tutulur (maddi) sosyal destek türlerinden (Tufan, 1994) yararlanmaları, onlara fayda sağlayabilir. Özellikle bu araştırmanın yürütüldüğü Burdur ili gibi yaşlı nüfusun Türkiye ortalamasının (2017 y1lsonu oranlarına göre; \%8,5'a karşl1ı \%14) oldukça üstünde olduğu (TÜIK, 2018a) bölgelerde yaşlılara yönelik uygulamaların ivedilikle faaliyete geçmesi, yaşlıların fiziksel ve psikososyal sağlıklarının korunmasını ve geliştirilmesini kolaylaştıracaktır. Bu bağlamda, araştırmacıların önerisi kapsamında, iller genelindeki Aile Sağlığı Merkezleri’nde öncelikli olarak yaşlılara hizmet ve danışmanlık vermek üzere sosyal hizmet uzmanlarının istihdamı uygun olacaktır. Sosyal hizmet uzmanları, yaşlının sosyal destek mekanizmalarının güçlendirilmesinde, yalnız ve korumasız yaşlıların savunuculuklarının yapılmasında, yaşlılar için gerekli kamu hizmetlerinin talep edilerek sağlanmasında, yaşlılara yönelik danışmanlık hizmetinin verilmesi ve ihtiyaç halinde periyodik olarak belirli hizmetlerden faydalanmalarının sağlanması gibi pek çok konuda destekte bulunabileceklerdir. Bunun dışında, illerde veya söz konusu illere yakın bölgelerde mevcut üniversitelerin ilgili fakültelerinde, geriatri ve gerontoloji anabilim dallarının açılması ve bu bölümlerden mezun olanların istihdam edilerek yaşlı bireylere yönelik profesyonel hizmetlerin sağlanması faydalı olabilecektir. Unutulmaması gereken bir diğer husus, yaşılıarda olumlu ve akılcı ilaç kullanımı davranışının geliştirilebilmesi için mümkün olan profesyonel hizmetlerin, yaşlı bireylerin evlerinde de verilebilmesidir. Bu kapsamda evde sağlık hizmetleri içinde de yaşlıya özel profesyonel hizmet boyutunun değerlendirilmesi gerekli görünmektedir.

NOT: Bu çalışma 26-29 Nisan 2018 tarihinde Antalya'da gerçekleştirilen Innovation and Global Issues in Social Sciences III'de sözlü sunum olarak sunulmuştur.

\section{Kaynaklar}

1. Abacıŏlu, N, 2005. Akılcı (Rasyonel) ilaç kullanımı. Bilim, Eğitim ve Düșünce Dergisi. 5 (4): $10-20$

2. Akan, P, Erdinçler, D, Tezcan, V, Beğer, T, 1999. Drug use in the elderly. Turkish Journal of Geriatrics. 2(1): 33-8.

3. Akgün T, 2016. 65 yaş ve üstü bireylerin ilaç kullanım durumlarının değerlendirilmesi. Uzmanlık Tezi, Akdeniz Üniversitesi Sağlık Bilimleri Enstitüsü, Antalya.

ISSN: 2148-2837
4. Arpacı, F, Açıkel, C, Şimşek, I, 2008. Ankara'da yaşayan bir grup yaşlının ilaç kullanım tutumları. TAF Preventive Medicine Bulletin. 7(6): 515-22.

5. Arslan, Ş, Atalay, A, Gökçe Kutsal, Y, 2000. Drug use in elderly. Turkish Journal of Geriatrics. 3(2): 56-60.

6. Aydoğdu Kocadağ B, 2016. Evde sağlık hizmetleri birimine kayıtlı 65 yaş ve üzeri hastalarda polifarmasi ve uygunsuz ilaç kullanımının değerlendirilmesi. Uzmanlık Tezi, 
Muğla Sitkı Koçman Üniversitesi Sağlı Bilimleri Enstitüsü, Muğla.

7. Blanco Reina, E, Ariza Zafra, G, Ocana Riola, R, Leon Ortiz, M, 2014. 2012 American Geriatrics Society Beers criteria: enhanced applicability for detecting potentially inappropriate 62 medications in European older adults? A comparison with the Screening Tool of Older Person's Potentially Inappropriate Prescriptions. Journal of American Geriatrics Society. 62(7): 1217-23

8. Bozkurt Bulakçı B, 2013. Yaşlılarda ilaç kullanımı ile ilgili tutum ve davranışlar. Uzmanlık Tezi, İstanbul Üniversitesi Sağlık Bilimleri Enstitüsü, İstanbul.

9. Collins M, 1986. Sampling, Consumer Market Research Handbook. McGraw-Hill press, London.

10. Ekenler, Ş, Koçoğlu, D, 2016. Bireylerin akılc1 ilaç kullanımıyla igili bilgi ve uygulamaları. Hacettepe Üniversitesi Hemşirelik Fakültesi Dergisi. 3(3): 44-55

11. Esengen, Ş, Seçkin, Ü, Borman, $\mathrm{P}$, Bodur, H, Gökçe Kutsal, Y, 2000. Drug consumption in a group of elderly residents in a nursing home: relationship to cogntive impairment and disability. Journal of American Medical Director Association. 1(5): 197-201.

12. Gökçe Kutsal, Y, 2006. Aging World. Turkısh Journal of Physical Medicine and Rehabilitation. 52: 6-11.

13. Gökçe Kutsal, Y, Barak, A, Atalay, A, Baydar, T, Küçükoğlu, S, Tuncer, T, Hizmetli, S, Dursun, N, Eyigor, S, Saridoğan, M, Bodur, H, Canturk, F, Turhanoglu, A, Arslan, S, Basaran, A, 2009. Polypharmacy in the elderly: a multicenter study. Journal of American Medical Director Association. 10: 486-90.
14. Gülhan, R, 2013. Yaşlılarda İlaç Kullanımı. Okmeydanı Tıp Dergisi. 29: 99-105.

15. Jhaveri, BN, Patel, TK, Barvaliya, MJ, Tripathi, C, 2014. Utilization of potentially inappropriate medications in elderly patients in a tertiary care teaching hospital in India. Perspectives in clinical research. 5: 184-9.

16. Kuvvetlioğlu, K, 2011. Yaşlı hastaların ilaç kullanım davranışları ve etkileyen faktörlerin belirlenmesi. Yüksek Lisans Tezi. Yakın Doğu Üniversitesi Sağlık Bilimleri Enstitüsü, Lefkoşa.

17. Şahin, G, Baydar, T, (2006). Use of drugs among older persons. In: Troisi J, Gökçe Kutsal, Y, (Eds) Aging in Turkey. GEBAM, Vertas Pres, Malta. 55-84.

18. Tufan, B, 1994. Göçmen İşçilerde İş Kazaları. Sosyal Sigortalar Kurumu Genel Müdürlüğü Yayınları, Ankara.

19. TÜİK, (2014). İstatistiklerle Yaşlılar, 2014. http://www.tuik.gov.tr/IcerikGetir.do?istab_id=2 65 (Erişim: 24.02.2018).

20. TÜİK, (2017). İstatistiklerle Yaşlılar, 2016. http://www.tuik.gov.tr/PreHaberBultenleri.do?id =24644 (Erişim: 24.02.2018).

21. TÜİK, (2018a). İstatistiklerle Yaşlilar, 2017. http://www.tuik.gov.tr/PreHaberBultenleri.do?id =27595 (Erişim: 04.04.2018).

22. TÜİK, (2018b). Nüfus Projeksiyonları, 20182080:

http://www.tuik.gov.tr/PreHaberBultenleri.do?id =30567 (Erişim: 24.02.2018).

23. WHO, (1985). Conference of experts on the rational use of drugs, World Health Organization, Nairobi, Kenya, WHO/CONRAD/WP/RI, 25-9. 